\title{
Silent City: A Commemoration of Halabja's Tragedy
}

\author{
MEHRENEGAR ROSTAMI
}

\section{Introduction}

One of The Silk Road Ensemble's well-received pieces, Silent City, commemorates Saddam Hussein's chemical attack in 1988 on the Iraqi Kurdish city of Halabja. Silent City was composed by the prominent Iranian kamancheh virtuoso, Kayhan Kalhor for the Silk Road Ensemble in 2005. The ensemble's musical collaboration memorializes the victims of Halabja in a performance that promotes the demand for justice through invoking the duty to remember. The Halabja genocide is often compared to the holocaust of Hiroshima. This genocide, however, has been ignored by the West and used as a propaganda tool by both Iranian and Iraqi governments in the Middle East. ${ }^{1}$ In contrast, the Silk Road Ensemble's performance of Silent City honors this tragedy through fostering a sense of intercultural hospitality as an exemplar of peaceful interactions.

\section{Memory, Testimony, and Remembrance}

In view of the ever-increasing presence of violence and war in today's world, scholars have become increasingly interested in examining the role of music in these situations of conflict. ${ }^{2}$ As a "commemorative practice" to keep alive the memory of tragic or triumphant events, music also figures prominently in post-war contexts. ${ }^{3}$ While many ethnomusicologists such as John H. McDowell and Svanibor Pettan have studied the commemorative role of music, they have been less concerned with the role of remembering in promoting justice. ${ }^{4}$ Drawing on the work of French philosopher Paul Ricoeur, I

\footnotetext{
${ }^{1}$ For a long time, there was an endless speculation over matters such as what lay behind the scenes, how the attack was staged, and who really was culpable. In the aftermath of the Halabja's attack, Iran was accused of using poison gas by the U.S. and some European countries. These countries were among main supporters of Iraq during the Iran-Iraq war. After the attack, the Iraqi government managed to postpone the UN investigation for several months. This investigation eventually revealed that the chemical artillery was sold to Iraq by its Western supporters. Although Saddam Hussain's government was identified as responsible for the genocide of Halabja, until today we still face much ambiguity about many dimensions of the event. For a detailed account of the chemical attack of Halabja, see Joost Hiltermann, A Poisonous Affair: America, Iraq, and the Gassing of Halabja (New York, NY: Cambridge University Press, 2007); and Debra A. Miller, Iraq (San Diego, CA: Greenhaven Press, 2004).

${ }^{2}$ See, for example, Jonathan Ritter, "Terror in an Andean Key: Peasant Cosmopolitans Interpret 9/11" in Music in the Post9/11 World, ed. Jonathan Ritter and J. Martin Daughtry (New York: Routledge, 2007), 177-208; Margaret Kartomi, “Toward a Methodology of War and Peace Studies in Ethnomusicology" in Ethnomusicology 54, no. 3 (2010): 452-83; John Morgan O'Connell and Salwa El-Shawan Castelo-Branco, Music and Conflict (Urbana: University of Illinois Press, 2010); J. Martin Daughtry, "Belliphonic Sounds and Indoctrinated Ears: The Dynamics of Military Listening in Wartime Iraq," in Pop: When the World Falls Apart; Music and Troubled Times, ed. Eric Weisbard (Durham, NC: Duke University Press, 2012), 111-44; Timothy Rice, "Ethnomusicology in Times of Trouble," in Yearbook for Traditional Music 46 (2014):191-209; Erica Haskell, "The Role of Applied Ethnomusicology in Post-Conflict and Post-Catastrophe Communities," in The Oxford Handbook of Applied Ethnomusicology, ed. Svanibor Pettan and Jeff Todd Titon (Oxford: Oxford University Press, 2015), 453-80; and Joshua D. Pilzer, “The Study of Survivor's Music," in The Oxford Handbook of Applied Ethnomusicology, 481-510.

${ }^{3}$ John H. McDowell, "Mexican Ballad as Commemorative Practice" in Music in the Post-9/11 World, ed. Jonathan Ritter and J. Martin Daughtry (New York: Routledge, 2007), 225.

${ }^{4}$ McDowell, "Mexican Ballad as Commemorative Practice;" Svanibor Pettan, "Music in War, Music for Peace: Experience in
} 
will relate the duty to remember to the requirement of justice by demonstrating how Silent City performs its role as a commemorative act.

In Memory, History, Forgetting, Ricoeur identifies the duty of memory with the demand to be "faithful to the past." For him, remembering is an act of recollection, an evocation, or simply calling forth of memories: "to say you will remember, it is also to say you will not forget." ${ }^{6}$ Memory thus raises a claim to truth that is formed "under the aegis of the epistemic fidelity of memories with respect to what actually took place." Ricoeur cautions that the failures of memory that are evident in instances of forgetting should not be regarded only as pathological, but are also sometimes "the shadowy underside of the bright region of memory, which binds us to what has passed before we remember it." ${ }^{8}$ Hence the duty to remember encompasses both negative and positive uses of memory, which Ricoeur refers to as "good use" and “abuse" of memory.

The border between the uses and abuses of memory is drawn by the way the duty to remember is announced. For Ricoeur, testimony is the "fundamental transitional structure" that connects memory to history. ${ }^{9}$ Since memory is the only resource for us in referencing the past, it is crucial to distinguish between false and reliable testimonies. Through credible testimonies, history provides a critical check on false memory, false testimony, and the like. Such testimony thus serves as a way of examining the "degree of fallibility belonging to memory." 10

In Ricoeur's view, a "critical agency" allows false testimonies to be unveiled, since this agency "oppos[es] those accounts reputed to be more reliable to the testimony under suspicion." 11 Although memories can be supported, corrected, and criticized only through a collective memory, this collective memory, Ricoeur therefore argues, "constitutes the appropriate counterpart to history." 12

Memory is also a technique of acquiring knowledge through the act of memorization. Both these perspectives (memorization and memorialization) represent the ways in which the past can be brought back and exercised. The role of duty to remember here is to bring these two perspectives together. The coming together of the truth and the pragmatic aspects of memory is put into effect by the federating force of justice. According to Ricoeur, the grammatical paradox implied in the phrase itself is an important feature of the duty to remember. There is a sense of "injunction" in the meaning of duty. When something demands to be remembered, it turns into a task that needs to be accomplished. The mere scale of the genocide in Halabja not only commands us to remember it but also makes it difficult to forget. In this respect, the creation and performance of Silent City by Kayhan Kalhor and the members of the Silk Road Ensemble serves both as an attempt in fulfilling this task and in reminding us that our failure to remember it, our oblivion, results in creation of false testimonies.

It is noteworthy that the duty to remember stands in marked contrast to memory as the

Applied Ethnomusicology," in Music and Conflict, ed. John M. O'Connell and Salwa El-Shawan Castelo-Branco (Urbana: University of Illinois Press, 2010), 177-92.

${ }^{5}$ Paul Ricoeur, Memory, History, Forgetting (Chicago: University of Chicago Press, 2004), loc. 99.

${ }^{6}$ Ibid., loc. 1352.

${ }^{7}$ Ibid., loc. 1374.

${ }^{8}$ Ibid., loc. 349.

${ }^{9}$ Ibid., loc. 362.

${ }^{10}$ Ibid., loc. 332 .

${ }^{11}$ Ibid., loc. 361; see also Ricoeur in Oneself as Another (Chicago: University of Chicago Press, 1992). Ricoeur sees testimony as a variation of attestation and explains that "the question of veracity, distinct from that of truth, stems from a more general problematic of attestation, which is itself suited to the question of selfhood: lies, deceit, misunderstandings, illusions all belong to this category." Ricoeur, Oneself as Another, 72.

${ }^{12}$ Paul Ricoeur, Memory, History, Forgetting (Chicago: University of Chicago Press, 2004), loc. 1841. 
"spontaneous evocation" of a past event. ${ }^{13}$ The duty to remember involves an act, which entails what Ricoeur calls an "active search." 14 This act can only take place when there is a time discrepancy between our primary impression of the past event, when it actually happened, and our recollection of its imprint in our minds. Thus, this interval of time enables the act of remembering to cross the temporal distance between the "initial impression" of an event and "its return." 15 Justice is capable of transforming memory into a project in the process of remembering, and of recovering the exemplary value of painful and upsetting memories. In turn, this project not only determines the "form of the future" but also evinces the sense of the imperative that is implied in the duty to remember. ${ }^{16}$

By introducing memory "as the womb of history," Ricoeur consequently ties the duty of memory to the idea of justice's federating force, the task of which is to unite the dual characteristic of the duty to remember. ${ }^{17}$ This dual characteristic consists of an inside and outside force. As a constraint, this inside force "is experienced subjectively as obligation." ${ }^{18}$ Conversely, the outside force often takes the form of manipulations that interpose themselves on the political and social aspirations. It is important to note that Ricoeur does not limit the understanding of memories' functions to a mere phenomenology of memory or an epistemology of history but directs us toward what he calls the "hermeneutics of the historical condition." 19

The connection between the duty of memory and the federating force of the idea of justice brings to the fore the latter's distinctive features. First, the idea of justice underscores "the component of otherness." 20 This sense of "otherness" is, in Ricoeur's view, intrinsic to all virtues but especially vital for justice. Hence, the duty to remember is at the same time an obligation to fulfill the demand for justice in light of memories that do not belong to oneself but to someone else. Second, the federating force of the idea of justice evinces the concept of a "debt," the meaning of which cannot be limited to "guilt." Since the concept of "debt" is closely linked to the notion of heritage, we feel indebted to those who lived before us and who formed the condition in which we find ourselves today. In other words, the heritage bequeathed to us by previous generations had a part of who we are now. In this sense, the duty to remember operates on two fronts. This duty not only requires us to preserve material elements from the past but also promotes the feeling of obligation towards those who played a role in shaping our heritage and to whom we are therefore indebted. Third, the federating force of justice prioritizes the victims of history. In sum, the duty to remember constitutes the "imperative of justice." 21

Finally, it is through memory that the relation between the present and past can be established. Ricoeur reminds us that the claim or demand to remember may run the risk of being interpreted as an invitation to privilege memory in order to circumvent the work of history. Therefore, he recommends that we not only examine the conflict zones between different kinds of memory-i.e., individual, collective, and historical-but that we are also attentive to the epistemology of historical knowledge. ${ }^{22}$ By providing a detailed analysis of Silent City together with an examination of its accompanying narrative, I will explain

${ }^{13}$ Ibid., loc. 1356.

${ }^{14}$ Ibid., loc. 296.

${ }^{15}$ Ibid., loc. 304.

${ }^{16}$ Ibid., loc. 1370.

${ }^{17}$ Ibid., loc. 1347.

${ }^{18}$ Ibid., loc. 1367.

${ }^{19}$ Ibid.

${ }^{20}$ Ibid., loc. 1380.

${ }^{21}$ Ibid., loc. 1423.

${ }^{22}$ Ibid. 
how this musical work commemorates the tragedy of Halabja. Through this act of remembrance, Kayhan Kalhor and other members of the Silk Road Ensemble have been able to raise awareness about this tragic event. I will therefore demonstrate how this act of remembrance, which is in the commemoration of the event, has given the piece a kind of political charge.

\section{The Chemical Attack in Halabja}

In the early afternoon hours of a spring day in 1988, just a few days before the Kurdish and Iranian New Year's ceremony, Nowruz, the small Kurdish town of Halabja with a population of ca. 70,000 was the target of a massive chemical bombardment. This occurred during the Iran-Iraq war, ${ }^{23}$ at which time I was eight years old. My father accompanied a group of Médecins Sans Frontières in the immediate aftermath of the attack. When I asked him if he can remember anything about Halabja, he responded:

I saw alleys with dead bodies, houses full of dead bodies, everywhere were dead bodies. I saw a father who had embraced a seven- or eight-year old girl in his arm ... Both were dead lying in an alley. ${ }^{24}$

Several thousand people died, mostly women and children, and many more were injured. Although chemical weaponry had been used on several occasions in the course of this war, it had never been used on such a large scale that resulted in massive annihilation. ${ }^{25}$ One of the survivors of Halabja describes the day of the attack in the independent Kurdish Online Newspaper, EKurd Daily. ${ }^{26}$ Since it gives a clear image of the order of incidents on the day of the attack, I quote his description in its entirety:

It was a beautiful spring day. As the clock approached 11:00 in the morning ... artillery rounds began to explode in Halabja and planes began dropping bombs on the town. The bombing was concentrated on the northern neighborhoods. So we ran and hid in our basement. At 2 o'clock in the afternoon, as the intensity of the bombing wound down, I carefully sneaked out of the basement to the kitchen and carried food to my family. When the bombing stopped, we began to hear noises that sounded like metal pieces falling on the ground. But I didn't find an explanation.

I saw things that I won't forget for as long as I live. It started with a loud strange noise that sounded like bombs exploding, and a man came running into our house, shouting, "Gas! Gas!" We hurried into our car and closed its windows. I think the car was rolling over the bodies of innocent people. I saw people lying on the ground, vomiting a green-colored liquid, while others became hysterical and began laughing loudly before falling motionless onto the ground. Later, I smelled an aroma that reminded me of apples and I lost consciousness. When I awoke, there were hundreds of bodies scattered around me. After that I took shelter again in a nearby

\footnotetext{
${ }^{23}$ The Iraqi regime's brutal act was apparently initiated by what happened three days before the attack: the Iranian troops allied with Kurd insurgents had taken control of Halabja. This meant a serious threat to Iraq. Not only could they advance further into Iraqi soil but could also, as historian Joost Hiltermann explains, reach a strategically important dam, which provided water and electricity to a wide range of cities and villages up to Bagdad. The explosion of this dam by Iranian troops would simply posit, according to Hiltermann, "an existential threat" to the regime by causing a flood to its capital, Bagdad. Convinced of the strong psychological and physical effects of chemical artillery, the Iraqi regime then employed them to take back control of Halabja, to subdue the Kurdish insurgency, and more importantly to force Iran to accept the peace agreement. Joost Hiltermann, A Poisonous Affair: America, Iraq, and the Gassing of Halabja, 7.

${ }^{24}$ Personal communication with the author, September 17, 2013.

${ }^{25}$ In this regard, Hiltermann states that "the Iran-Iraq war witnessed the introduction of gases never seen in battle before, including possibly [Venomous Agent X, aka] VX, a highly lethal nerve agent.... Poison gas had never before been used against populated areas; in breaching this moral barrier, the Halabja attack set a dangerous precedent." Hiltermann, $A$ Poisonous Affair, 15.

26 "Halabja: Survivors Talk about Horror of Attack, Continuing Ordeal," Ekurd Daily: Independent Daily Newspaper, March 15, 2008 .
} 
basement, the area was engulfed by an ugly smell. It was similar to rotting garbage, but then it changed to a sweet smell similar to that of apples. Then I smelled something that was like eggs. Sometime later, I discovered that the Iraqi air force had bombed Halabja with chemical weapons. ${ }^{27}$

Memories of that day are still present in the minds of both survivors and observers. It is not possible to fully describe what people really experienced or felt. In "Music in War, Music for Peace: Experiences in Applied Ethnomusicology," Svanibor Pettan states that "wars and other violent conflicts stimulate musical creativity and thus call for the attention of researchers." 28 The tragedy of Halabja provided a motivation for Kayhan Kalhor and members of the Silk Road Ensemble in creating Silent City in response to the suffering inflicted on the victims. This piece invokes an ethos that reverberates with the trauma of Halabja. Kalhor and the members of the Silk Road Ensemble thus not only keep the memory of the victims of Halabja alive but also give expression to what cannot be put into words.

\section{The Silk Road Encounter and Musical Collaborations}

The first encounter of Kalhor and other performers of Silent City took place in the context of Yo-Yo Ma's Silk Road Project. ${ }^{29}$ In my 2013 interview with Kalhor, he explained the way he came to know musicians of the Silk Road Ensemble:

Around fifty to sixty musicians from all over the U.S. had been chosen to join the [Silk Road] project .... After a while many of [the] musicians left and many stayed. Brooklyn Rider's musicians were among those people who remained. However, only two of them were there [in the Silk Road Ensemble]. Colin Jacobsen, who plays the violin, and Nicholas Cords, who plays the viola. After the project started, we got to know each other and became friends.... At some point, then, another violinist called Johnny Gandelsman, who is Israeli Russian, joined us. And also Colin's brother [Eric Jacobsen], a cellist who worked with us sometimes.... Because they were all friends with each other, they started establishing a [string] quartet, which emerged from the Silk Road Ensemble.... We started working with each other. We composed pieces together and performed them at concerts. During those concerts, we became very close to each other. Our relationship was not limited to work. We used to go out and have dinner together. ${ }^{30}$

In 2005, the composer of the piece, Kalhor was commissioned by Harvard University to write a piece for Harvard's music appreciation class called First Nights. Kalhor, who has a Kurdish background, is a member of the Silk Road Ensemble, musicians of which has been artists-in-residence at Harvard since 2005. In the class First Nights, world premières of important historical works and new compositions were discussed and studied. Moved by the tragic chemical attack on Halabja, Kalhor dedicated Silent City to the victims of that tragedy. The piece was developed and realized in close collaboration with four members of The Silk Road Ensemble, who later formed the string quartet, Brooklyn Rider, and the co-arranger, Lev Ljova. Two years after its Harvard première, the piece was recorded as part of New Impossibilities (2007) by Yo-Yo Ma and the Silk Road Ensemble and a year later, it was recorded again as the title track of a four-

\footnotetext{
${ }^{27}$ Ibid.

${ }^{28}$ Pettan, "Music in War, Music for Peace," 177.

${ }^{29}$ Envisioned by the celebrated cellist Yo-Yo Ma in 1998 as a globally-oriented, performing-arts venture, the Silk Road

Ensemble is the visage of a greater enterprise called the Silk Road Project.

${ }^{30}$ Kayhan Kalhor, personal communication, March 4, 2013.
} 
piece album by Kalhor and the musicians of Brooklyn Rider: Colin Jacobsen, violin; Nicholas Cords, viola; Johnny Gandelsman, violin; and Eric Jacobsen, cello. Silent City, 29' 10” in length, is the longest piece of this recording. ${ }^{31}$

Video 1: The Silk Road Ensemble: Silent City

View at: http://dx.doi.org/10.3998/mp.9460447.0011.105

Silent City is based on a model for intercultural musical interactions that emerge from Yo-Yo Ma's Silk Road Project. Ma employs Silk Road "as a metaphor for sharing and learning across cultures, art forms and disciplines." ${ }^{2}$ In his view, "Silk Road ... stand[s] for the interconnectedness of peoples who were separated by vast distances, and indeed by decades and centuries... This commingling of history and metaphor is what makes the Silk Road such an evocative symbol of cultural exchange and connection." ${ }^{33}$ Historian and Silk Road scholar Tamara Chin refers to Ma's vision as a "reinvented Silk Road" that is based on a "model of idealized exchange." 34 This reinvention, Chin argues, is not only reminiscent of the past, but also provides hope for the future.

In Kalhor's view, the friendship that developed between him and the musicians of Brooklyn Rider (an off-shoot of the Silk Road Ensemble) has played a crucial role in their collaborative creation of Silent City. Colin Jacobsen also sees Silent City as the result of a long-term friendship and collaborative work:

Silent City couldn't have happened when we first met Kayhan because we didn't know much about Persian music; [we had not yet had] many of our conversations with Kayhan, which involved talks about [our] shared love for the music of John Adams. [He] is a wonderful composer from the Western tradition who has expressed admiration for Kayhan as well. We talked about how much we all loved the piece Shaker Loops. ${ }^{35}$

Violist Nicholas Cords emphasizes the role their longstanding relationship has played in the creation of Silent City in his interview with Vivien Schweitzer for The New York Times: "We enjoyed each other on the first meeting and were fascinated with his world, but at the beginning wouldn't have dreamed of making this recording together." ${ }^{36}$ Schweitzer following Nicholas Cords explains that "Silent City' is the result of eight years of learning and experimentation." ${ }^{37}$ In Playing across a Divide: Israeli-Palestinian Musical Encounters, Benjamin Brinner also indicates that a "common understanding" of each other's musical style is the result

\footnotetext{
${ }^{31}$ Ascending Bird (6:54), Parvaz (06:23), and Beloved Don't Let Me Be Discouraged (10:33) shape the first, third, and fourth piece on the Album. Ascending Bird, an arrangement by Brooklyn Rider's violinist Colin Jacobsen and the Iranian adept santur (the Iranian hammered dulcimer) player, Siamak Aghayi, is a composition with an accelerating tempo based on a traditional folk melody (the title of this track refers to the story of a mystical bird in Persian literature that just like the phoenix ascends towards the upper levels of the sky and after uniting with the sun, reappears from his ashes [Losinski, “"Ascending Bird' Silk Road Ensemble”]). Mark Suter (percussionist), Jeff Beecher (bassist), and Siamak Aghayi (santur player) are the added line-up to this track. Parvaz is another composition by Kayhan Kalhor that features him on the setar (the Iranian long-necked lute). The last track is a composition by Colin Jacobsen who took inspiration from the Persian classic poem Leyli $\mathcal{G}$ Majnun (completed in 1192) by the twelfth-century poet Nezami Ganjavi and a fourteenth-century Italian song. Joe Tangari, "Kayhan Kalhor and Brooklyn Rider: Silent City," in Pitchfork, January 23, 2009.

${ }^{32}$ See The Silk Road Project, "The Silk Road Fact Sheet," 2014. The term not only recalls the images of the historical routes where "precious" goods were traded, but "also [stands] for the ideas that travelled in both ways." James Cuno and Yo-Yo Ma, "The Silk Road and Beyond," Art Institute of Chicago Museum Studies 33, no. 1 (2007): 21.

${ }^{33}$ The Silk Road Project, "Fact Sheet."

${ }^{34}$ Tamara Chin, "The Invention of the Silk Road, 1877," Critical Inquiry 40, no. 1 (2013): 194.

${ }^{35}$ Colin Jacobsen, personal communication, April 6, 2013.

${ }^{36}$ Quoted in Vivien Schweitzer, “A Master Iranian Musician Plays Cultural Ambassador,” The New York Times, August 26, 2008.

${ }^{37}$ Ibid.
} 
of a "prolonged interaction with one another," which can be "built up over years of shared experience." 38

Musicians of Brooklyn Rider were able to "find a way to relate to Persian music" and get a sense of ornamentation and repetition, which can be found in minimalist music as well, through listening to the music of minimalist composers, as Colin Jacobsen elucidates. ${ }^{39}$ Their shared love for musical texture as heard in the music of minimalist composer John Adams is mirrored in the improvised movements of Silent City. Furthermore, in the course of touring with the Silk Road Ensemble, Brooklyn Rider musicians heard Kalhor's improvisations and played the first piece that Kalhor had composed for the Silk Road Ensemble, Blue as the Turquoise Night of Neishabur (2001). ${ }^{40}$ This piece helped them "get his sound and the sound of Persian music in [their] ear" ${ }^{41}$ and learn "the beauty of staying within one mode or scale and fully exploring it." ${ }^{* 2}$ Colin Jacobsen and Nicholas Cords travelled to Iran to learn more about Kalhor's native musical tradition and the role improvisation plays in it. Their two-week stay enabled them to study the radif, the repertoire of Iranian traditional music, with Kalhor. ${ }^{43}$

In addition to acquainting themselves with the radif, Brooklyn Rider also became familiar with the art of architecture and poetry, which helped them better understand the philosophy behind Iranian art and music. ${ }^{44}$ Colin Jacobsen states that

having gone to Iran, visited Kayhan and having seen beautiful mosques and calligraphers' works [as well as] the philosophy in connection behind many of the things that represented the music, I think, led us to believe that we could improvise together because we knew something more than we did when we first met him. ${ }^{45}$

Kalhor has been, in Colin Jacobsen's term, a "great guide" into improvisation, especially within the framework of Iranian traditional music. Colin Jacobsen explains that "Kalhor would describe and give us [musical] examples of the radif [through which we] could understand the vocabulary behind the music." Knowing this vocabulary not only aided improvisation in Silent City and other pieces Kalhor wrote for Brooklyn Rider, but also encouraged Colin Jacobsen and Nicholas Cords to start composing pieces themselves in which they make use of improvisation: "my desire to write something that brought together Kayhan's world and ours was very inspired by shared experiences and many conversations just about other music that we like." 47

My interviews with Brooklyn Rider's musicians revealed that they not only look upon Kalhor as their teacher-one who taught them aspects of Iranian music and how to improvise-but that Kalhor is also like an older brother to them. It would not be an exaggeration to compare their relationship to that of

\footnotetext{
${ }^{38}$ Benjamin Brinner, Playing across a Divide: Israeli-Palestinian Musical Encounters (Oxford: Oxford University Press, 2009), 262.

${ }^{39}$ Colin Jacobsen, personal communication, April 6, 2013.

${ }^{40}$ This piece was released on The Silk Road fourneys: When Strangers Meet by Yo-Yo Ma and The Silk Road Ensemble in 2001.

${ }^{41}$ Colin Jacobsen, personal communication, April 6, 2013.

${ }^{42}$ Colin Jacobsen, personal communication, July 5, 2013.

${ }^{43}$ The radif (lit. rows) is a collection of melodic models that form the canonic repertoire of Iranian traditional music. These models, which serve the basis for improvisation, are systematically divided into seven primary melodic sets or modes known as dastgah (pl. dastgah-ha) and five secondary sets known as avaz or mayeh. In a later classification of the radif by Hormoz

Farhat, these melodic sets are divided into twelve dastgah-ha. Today, Iranians work with about six or seven well-known radifha, collected and developed by different masters. Hormoz Farhat, The Dastga $h$ Concept in Persian Music (Cambridge:

Cambridge University Press, 2004).

${ }^{44}$ Although it is not possible to learn the whole radif in such a short time, Colin Jacobsen and Nicholas Cords' two-week stay enabled them to play some parts of the radif with Kalhor and learn its role and significance in the Iranian traditional music.

${ }^{45}$ Colin Jacobsen, personal communication, April 6, 2013.

${ }^{46}$ Colin Jacobsen, personal communication, July 5, 2013.

${ }^{47}$ Ibid.
} 
a guru and his followers. While for Kalhor it was quite important to be acknowledged as the composer, as well as teacher and leader, he always emphasized his close relationships with the musicians of the Silk Road Ensemble and Brooklyn Rider. The musicians' emphasis on their rapport suggests that they clearly wanted to avoid any suggestion of a hierarchical order as it usually exists in both Iranian traditional and Western classical music contexts. At the same time, Kalhor's solo improvisation in the middle of the piece alludes to the centrality of his role inasmuch as he is the only one who performs a solo in the piece, he is usually the one who introduces the leading motif, and he has the leading role both in the group improvisation and in the compositional part of the piece. ${ }^{48}$

For Silent City's musicians, their long-term friendship is an important factor that differentiates them from other collaborative musicians who do not necessarily learn about the other's culture or, if they do, their engagement with the other culture remains at a surface level. It also differentiates them from their own music making in the context of the Silk Road Ensemble.

In Colin Jacobsen's view, Silent City provided the chance for them to expand their collaboration with Kalhor. He explains,

Within the Silk Road Project, there are so many different traditions that are being represented. We play with Chinese or Indian musicians, many different kinds of pieces. So, there isn't as much time to go really deep into one thing. So, we decided to make this album and go further with that collaboration. ${ }^{49}$

Apart from being commissioned by Harvard University, two other factors initiated the creation of Silent City and collaboration between Kalhor and musicians of Brooklyn Rider: first was Brooklyn Rider's interest in improvisation, as Kalhor explains: "they always liked bedahe navazi (improvisation). Since they have played the radif with me... they always liked to do a work together that it isn't written down." ${ }^{50}$ Colin Jacobsen also explains that "[Silent City] was a way to go further with many ideas that we'd been talking about for many years in terms of improvisation." 51 The second factor that led to the creation of Silent City was the tragedy of Halabja. As alluded to earlier, Kalhor used the memory of this tragedy as a source of inspiration and dedicated the piece to its victims.

\section{Silent City: A Musical Description}

My analysis of Silent City is based on its studio recording by Brooklyn Rider, though at times I refer to a video recording of one of the ensemble's live performances, which took place at Brooklyn Lyceum in New York in January 2008. ${ }^{52}$ The piece is structured in four parts: "Introduction" (group improvisation,

\footnotetext{
${ }^{48}$ The way members of the Silk Road Ensemble/Brooklyn Rider and Kalhor view their collaborative music-making is congruent with ethnomusicologist Jason Stanyek's definition of intercultural musical encounters, which emphasizes the intercorporeal interactions of musicians with disparate cultural backgrounds (see Stanyek, "Diasporic Improvisation and the Articulation of Intercultural Music," [PhD diss., University of California, San Diego, 2004]). This collaboration goes even one step further because "friendship" does not play a significant role in Stanyek's view of intercultural encounters. In retrospect, I realized that by giving emphasis to the process of learning and friendship, these musicians wanted to make it clear that Silent City is unlike many, perhaps most, other hybrid musical products in the market that are, in Stanyek's sense, cross-culturally produced. (In such productions, native musicians of the non-Western countries often do not have any control over the end-product; for a more detailed discussion of cross- and intercultural music productions see Stanyek, "Diasporic Improvision and the Articulation of Intercultural Music.”)

${ }^{49}$ Colin Jacobsen, personal communication, April 6, 2013.

${ }^{50}$ Kayhan Kalhor, personal communication, March 4, 2013.

${ }^{51}$ Colin Jacobsen, personal communication, April 6, 2013.

${ }^{52}$ A recording of this performance is available on YouTube, https://www.youtube.com/watch?v=8WzIxBeJ78U.
} 
led by Kalhor); "Echoes" (group improvisation, led by Kalhor and Colin Jacobsen); "Chant" for kamancheh (solo improvisation by Kalhor); and the Composed Part (composed/co-arranged for the whole group by Kalhor and Lev Ljova). Silent City is a piece that is formed through the encounter of two distinct musical traditions: Kurdish/Iranian traditional and Western classical musics.

Video 2: Kayhan Kalhor and Brooklyn Rider: Silent City

View at: http://dx.doi.org/10.3998/mp.9460447.0011.105

In creating Silent City, Kalhor makes use of both improvisational and compositional styles. The improvised part forms the first and the largest part of the piece. It encompasses a group and a solo section. Kalhor describes the group-improvised movements in the Persian liner notes of Silent City:

The compositional style in the first [three] sections of the piece is unusual and based on signs. In this style, each musician performs his own interpretation of the signs. The forms and the general direction of the piece are the only elements that have been determined and explained, components such as tempo, rhythm, range and combining choices are naturally variable in each performance and depend on the musician. ${ }^{53}$

In his 2011 interview on Silent City, Kalhor emphasizes that the improvised movements are based on certain rules. These rules are, however, not explicitly determined. For him, the indeterminacy of those elements makes the piece more interesting and gives them the liberty to perform it differently each time. ${ }^{54}$ In Kalhor's view, the improvised part in Silent City provides one with the opportunity to employ his tasavor (imagination). The piece would not blossom well if the musicians did not have enough courage to do improvisation. Kalhor employs an eloquent "picnic" metaphor to elaborate upon the contribution of the musicians in this piece:

There are moments that someone is playing a very high harmonic... something very unusual and he thinks he is helping in that way. It is like going to a picnic. You bring sandwiches, I bring drinks, someone else brings eggs, and someone brings bicycles or whatever...It works like that. Ultimately what we do is that we all eat together. If you do not want to take part in it or you have fears or you don't agree with it or believe in it, naturally the result of the work won't be successful. ${ }^{55}$

For Colin Jacobsen, the improvisation in Silent City is more like a "musical landscape," in which they improvise based on one scale, which is the Iranian mode shur. Colin Jacobsen describes how they approach shaping the "musical landscape" of Silent City:

You are painting a picture and so the details are important, but you need to just keep [going]. You need to stay very in the moment and thinking very horizontally and also trust being [with] each other because in terms of creating a musical landscape you aren't responsible for the whole picture. You're just part of it. ${ }^{56}$

This "musical landscape" provides them with a "shared space," to use Colin Jacobsen's term, through which they can interact. Colin Jacobsen further explains that an important factor that helped shape the structure of the piece was the "shared narrative" among them:

\footnotetext{
${ }^{53}$ Quoted in Hamidreza Afarideh, "Bozorgan-e Musiqi Sonnati-e Iran.” The translation is mine.

${ }^{54}$ Kalhor, "Silkroad: Kayhan Kalhor on 'Silent City,” August 24, 2011.

${ }^{55}$ Kayhan Kalhor, personal communication, March 4, 2013.

${ }^{56}$ Colin Jacobsen, personal communication, April 6, 2013.
} 
This piece is about a city, where something terrible from man-made things has caused devastation. So, we are starting from a place of barren landscape. Slowly, there is a sense of life returning through the piece. It's like in reverse time. The natural cycle of something being destroyed and coming back to life. We're always sharing the same narrative. ${ }^{57}$

This shared narrative is also crucial in creating a sense of trust among the musicians. It provides them with the tool to interact with each other and go on a musical journey together, which has a specific goal. This goal is the narrative itself: they portray the story of Halabja and they act as the harbingers of hope. Cords also emphasizes the role of narrative in this piece:

To me, the piece exists as a sort of narrative. It tells a very strong kind of [tale] and the arch of narrative is very clear. I think of this music as a story telling. Not in a sense of this happened and then this happened. There's a clear sort of emotional story telling what happened. ${ }^{58}$

Also for Cords, portraying this story through improvisation is enabled by their mutual trust. This trust has been achieved, as indicated earlier, through their friendship and long-standing relationship. The musicians of Silent City each play a crucial role in illustrating a part of the musical scenery that is intended to be drawn in the course of its performance. They have chosen improvisation as the medium of their "musical discourse," because it gives them the freedom to be in the moment and interact spontaneously. ${ }^{59}$ Every performance of Silent City is what Nicholas Cords calls a "momentification." This means each performance is different from the others, even though they might perform the piece ten times a year. As Cords elucidates: "We challenge ourselves to never create the same performance. Nobody ever says, 'Oh, remember last concert when this happened, it was so great. Let's try to do that again.' We never rehearse the improvised part." ${ }^{\prime 1}$ For Cords, improvisation is something that they, as he further explains, "share and explore in real time with the audience." 62

In contrast to the solo movement, the group improvisation does not conform to the Iranian traditional music episteme. The group improvised movements are performed in a rather free style and differ significantly from Kalhor's solo improvisation, which is played within the framework of Kurdish/Iranian traditional music. The group improvisation is structured and based on Kalhor's instructions. These instructions include the type of scale, dynamic, pitch, and also how their playing can be coordinated. For instance, musicians of Brooklyn Rider were asked to start with playing sustained, piano, open notes in the scale Kalhor had previously determined. The improvisation could be started from any pitch but it had to be started from a low pitch ascending to a higher one. The pitches had to be changed randomly at different times. The musicians just had to avoid a chord change. In other words, they weren't bound to any timeline and they had the independence to play new pitches spontaneously. It was important that pitch changes did not happen at the same time. Playing simultaneously would suggest the existence of a harmony, which Kalhor wanted to circumvent thoroughly in the group improvised movements.

It was of great significance for him that the group improvisation implied a sense of suspension and

\footnotetext{
${ }^{57}$ Ibid.

${ }^{58}$ Nicholas Cords, personal communication, July 10, 2013.

${ }^{59}$ George Lewis, "Improvised Music After 1950: Afrological and Eurological Perspective," in The Other Side of Nowhere: Fazz, Improvisation, and Communities in Dialogue, ed. Daniel Fischlin and Ajay Heble (Middletown, CT: Wesleyan University Press, 2004), 132.

${ }^{60}$ Nicholas Cords, personal communication, July 10, 2013.

${ }^{61}$ Ibid.

${ }^{62}$ Ibid.
} 
unpredictability: "I wanted to be a thing that feels like suspending in the air. Something that cannot be guessed." ${ }^{63}$ The sense of suspension and unpredictability is a means for Kalhor to express an "irregularity" that is contained in a "regularity." Kalhor is particularly expressive about this issue. He connects the hidden regularity of the group improvisation to the concealed order of the galaxy:

When you enter a vacant space, when you go out of the globe, everything is in order, but you cannot really see the order. Everything has a continuation. There is a silence. Everything is the way it is. All the celestial stones come and pass beside you. The planets live their own lives. Everything has an order but there is also a kind of irregularity, which makes you think where you are, in the air or on the earth. [You ask yourself] where your place is. Something like an irregularity in regularity: [in Persian] "binazmi dar eyne nazm."

An orchestrated piece would represent order that would not match the story Kalhor intended to tell in the improvised movements. Since he wanted to depict the story of Halabja, he employed the irregularity of sounds in the group improvised movements to demonstrate the chaotic condition resulting from the chemical attack. In Kalhor's view, the piece is a reverse representation of the order of events in Halabja:

It's not like that something is being prepared and then situation gets worse and a bomb drops down. It starts from a bad situation and gradually the situation becomes better. The piece starts from a place, where there is no life, there is no hope. Then, gradually, hope comes in. The echoes that are part of the improvisation represent hope for life as it returns slowly. ${ }^{65}$

To achieve the regularity hidden in the irregular sounds, the performers, according to Kalhor, should listen to each other's playing. He emphasizes the importance the role listening plays in performing Silent City and elucidates how they learnt about group listening: "We have learnt listening to each other very well in the process of making music in the Silk Road Ensemble. That's the key point for performing this piece. If you don't listen to the person beside [sic] you, you won't be able to perform it." 66

In describing the general structure of the piece, Kalhor explains that the whole piece could not be improvisatory, and that's "because when five people play together, it is not like one person doing it. They should have some arrangements with each other. Otherwise, it will be chaos." ${ }^{67} \mathrm{He}$ further elucidates that he first wrote the composed movement. After arranging its orchestration, he prepared an introductory part in his mind, which would be followed by the composed movement.

In contrast to the group improvisation, a transparent harmony can be heard in the composed part, which was partly added by Lev Ljova. The composed movement signifies a sudden shift in the life of people, as Kalhor explains:

After an elegy that is played by the kamancheh, the life suddenly comes back to that place in a gentle manner. In fact, the orchestrated part represents the people who have decided to help each other. The life comes back and people's souls return to that place. ${ }^{68}$

An important constitutive factor in the creation of Silent City is its mode. Silent City is based on dastgah-e shur, which is among the most important modes in the radif of Iranian traditional music. This mode is not only pivotal in shaping the piece musically, but also interculturally. In Kalhor's view, dastgah-e shur is a mode that is present in a wide range of musical traditions and thus has resonance across cultures.

\footnotetext{
${ }^{63}$ Kayhan Kalhor, personal communication, March 4, 2013.

${ }^{64}$ Ibid.

${ }^{65}$ Ibid.

${ }^{66}$ Ibid.

${ }^{67}$ Ibid.

${ }^{68}$ Ibid.
} 
Indeed, he employs a rhetoric that lends shur a universality, thus implying that its prevalence makes understanding, performing, and communicating with the piece easier. "This scale exists [in] China, [in] the Muslim-settled areas of China, which have been under the influence of Iranian music, to North Africa. It exists everywhere." ${ }^{69}$ The structure of shur, as Kalhor argues, is also quite similar to that of A minor in Western classical music: "with a slight change in its second degree, it can sound like Western music and if you move your finger forward [on kamancheh] and play the second degree sharper, it becomes our own shur. If you play it even sharper, it changes to one of the Kurdish maqams." ${ }^{70}$

Since shur is more flexible than other modes within the Iranian radif, it can be easily integrated with other musics. Kalhor explains that this is why he chose this mode for Silent City: "You can spontaneously modulate and get a Western or Eastern sound.... and also, it was much easier for members of Brooklyn Rider to have only one accidental. They would just need to only change one pitch or quartertone." ${ }^{71}$ In one of my conversations with Colin Jacobsen, he also pointed out that Silent City was easier to play in comparison with another of Kalhor's pieces, which they had played with the Silk Road Ensemble. That is because Silent City contained fewer pitches that fall outside Western scales. In other words, Brooklyn Rider's musicians were better able to assimilate shur than other modes, thus facilitating improvisation.

Another reason for choosing shur as the basis for Silent City was that Kalhor believed it could speak to a broad audience, again due to its pervasiveness and recognisability. Kalhor elucidates, "I wanted that everyone could find a connection to this piece. I didn't want to be something very esoteric. So, that they had to know a particular kind of music to be able to understand this scale." 72 At the same time, shur is typical of Iranian and Kurdish traditional music; in Kalhor's own words, it is the "mother of dastgah-ha" in the radif..$^{73}$ The melodic theme Kalhor employs in the composed part is a Kurdish folk tune, also based on shur. The "nostalgic" and "upsetting" moods that this mode can conjure was an important factor in Kalhor's modal choice: "You can find a state of sadness in this mode. I wanted this piece to bring that in mind." ${ }^{74}$

\section{Halabja's Reflection in Silent City}

The piece begins with long-sustained notes that are played ad lib by all musicians involved in its performance. The introductory part can be interpreted as a musical depiction of the silence that hung over the city in the aftermath of the attack. As the piece evolves, more layers of sounds are added. The music does not have any particular melodic theme. After the introductory part, the musicians start echoing each other in a chaotic fashion. No obvious structure can be heard in this part. The tempo becomes faster. The music becomes louder. The musicians keep adding more improvisatory pitches till they reach the climax and suddenly stop playing. These echoing sounds can be heard as evoking the chaos and confusion among the survivors. This part is followed by the composer's solo improvisation. For the first time, a clear melody, a familiar one can be heard. The melody has a popular Kurdish theme. Although the string

\footnotetext{
${ }^{69}$ Ibid.

${ }^{70}$ Kayhan Kalhor, personal communication, June 26, 2013.

${ }^{71}$ Ibid.

${ }^{72}$ Ibid.

${ }^{73}$ This opinion is also shared by Iranian musicologist Hormoz Farhat: "Šur is in some respects the most important of the dastgāhs. It contains a large body of pieces, and its domain belongs to at least two secondary dastgāhs, Abuatā and Dašti. A great many of folk tunes, from different parts of Persia, are founded on the modal schemes of $\breve{S}$ ur or its derivative dastgāhs and gušes." Farhat, The Dastgāh Concept in Persian Music, 27.

${ }^{74}$ Kayhan Kalhor, personal communication, June 26, 2013.
} 
quartet accompanies the composer in this part, their sound can only be heard in the background. The sound of kamancheh, on the other hand, becomes dominant. Its piercing sound resembles the sound of wailing and mourning. For Kalhor, the mode of shur on which the "Chant" is based, is "basically A minor scale with a different second." ${ }^{75}$ In this form, the mode is particularly prevalent in the northern part of Iran and the eastern part of Turkey. This scale, according to Kalhor, "has a special sound that makes it sounds Kurdish," 76 which is mostly due to the distinct tuning and frequent appearance of B-koron (approximately a quarter-tone higher than B-flat).

Although Kalhor was born in Tehran, he comes from a Kurdish Iranian family. He learnt Kurdish music from his parents and from his many travels to the Kurdish cities in the western part of Iran. The reason, however, for choosing a Kurdish theme for Silent City cannot only be ascribed to his interest in Kurdish music. In explaining why he chose a Kurdish theme for Silent City, Kalhor emphasizes the significance of Halabja's tragedy and its long-lasting effect on him. When he got the chance to compose this piece, he knew "[it] should have a Kurdish theme." ${ }^{77}$ His aim was to portray the story of people who were the victims of Saddam Hussein's chemical bombardment of Halabja. In so doing, not only did he want to commemorate the tragic event of Halabja but also to invite those to whom the story is still unknown to envision it:

Some years ago, the small [Iraqi-Kurdish] city of Halabja was bombed by Saddam Hussein and over 10000 people were dead. Nobody really talked about it and nobody knew what happened in the West. That was a very, very sad event. When I heard it, ... it affected me greatly and I ... just saw pictures, truly terrible pictures of it. I just had it in front of my eyes wherever I went for a couple of months. It wasn't easy to forget. I always wanted to do something to remember that. And I think Silent City in some way[s] was dedicated to Halabja. I hope it helps people remember it. Or, if they don't know what happened there, want to think about it. $^{78}$

The kamancheh's elegy represented by Kalhor's solo improvisation lasts around three minutes in both the studio recording and live performances. The end of the "Chant" marks the end of the improvised part in Silent City. The piece takes an unexpected turn and a festive and cheerful melody with a dance rhythm is introduced. In the final part of the piece, which as pointed out earlier is composed, musicians start playing together more harmoniously. A dance motif is introduced that heralds the upsurge of joy. Dissonances can be heard less frequently. The mood of the piece changes significantly, sublimating the feeling of the sorrow of the tragedy. The musicians announce the advent of hope. The use of harmony in the final part serves as a symbol of conflict resolution. ${ }^{79}$

\section{Concluding Remarks}

Silent City emerged at a time of ever-increasing crisis in political relations among the musicians' native countries. The significance of an Iranian and a group of American/Israeli musicians coming together in an era where the antagonism between their countries takes more hostile form every day cannot be ignored. Today, in January 2017, more than a decade after the creation of the piece, we are facing another

\footnotetext{
${ }^{75}$ Kalhor, “Silkroad: Kayhan Kalhor on 'Silent City,” August 24, 2011.

${ }^{76}$ Ibid.

${ }^{77}$ Kayhan Kalhor, personal communication, March 4, 2013.

${ }^{78}$ Ibid.

${ }^{79}$ See O'Connell and Castelo-Branco, Music and Conflict.
} 
war among different ethnic and political groups in the very same region where the Halabja tragedy occurred twenty-six years earlier. By recalling the memories of Halabja, Silent City not only enlivens the past but also recognizes our debt to the victims of this tragic event. In so doing, it calls for justice. As a project of remembrance, Silent City is more than a mere reminder of a past tragedy; remembrance is, following Ricoeur, accentuated by the activity that constitutes it. Silent City, which is performed by a group of musicians who are not from the region, not only helps raise awareness and advance knowledge about a past historical event but also evinces the duty to remember through evoking the memories of Halabja, thereby promoting the obligation to remember the victims of this tragedy in the name of justice. By commemorating the tragedy of Halabja through musical sounds, Kalhor and the musicians of Brooklyn Rider and the Silk Road Ensemble honor the victims of Halabja. In summoning the story, the musicians not only keep the memory of the victims of Halabja alive but also offer an alternative way of lamenting and expressing compassion for them.

Furthermore, Silent City not only depicts hope of life for the people of this region but also delineates an idealized space for peaceful dialogue and intercultural exchange among musicians with disparate cultural backgrounds that promotes the idea of intercultural hospitality. The collaboration of Kalhor and members of the Silk Road Ensemble would not be possible without their friendship. Their long-lasting relationship that resulted in their musical collaboration in Silent City represents an alternative model for productive communication and intercultural exchange. Indeed, as Kalhor once described it, Silent City functions as a "monument" - a musical "monument," which can represent a model for peaceful interaction. ${ }^{80}$ In The Human Condition, Hannah Arendt argues that "since action acts upon beings who are capable of their own actions, reaction, apart from being a response, is always a new action that strikes out on its own and affects others." ${ }^{81}$ I believe that the composer's initiative in creating this piece provides a handhold for hope that has gained sociopolitical meanings by commemorating the tragic event of Halabja and demanding justice.

\section{References}

Afarideh, Hamidreza. "Bozorgan-e Musiqi Sonnati-e Iran [Pioneers of Iranian Traditional Music].” Afarideh Blog, April 21, 2009. Accessed December 16, 2016. http://afarideh4.blogfa.com/cat169.aspx.

Arendt, Hannah. The Human Condition. Edited by Margaret Canovan. Chicago: University of Chicago Press, 1998. https://doi.org/10.7208/chicago/9780226924571.001.0001.

Brinner, Benjamin. Playing across a Divide: Israeli-Palestinian Musical Encounters. Oxford: Oxford University Press, 2009. https://doi.org/10.1093/acprof:oso/9780195395945.001.0001.

Chin, Tamara. “The Invention of the Silk Road, 1877." Critical Inquiry 40, no. 1 (2013): 194-219. https://doi.org/10.1086/673232.

Cuno, James and Yo-Yo Ma. "The Silk Road and Beyond: A Conversation with James Cuno and Yo-Yo Ma." Art Institute of Chicago Museum Studies 33, no. 1 (2007): 20-29.

Daughtry, J. Martin. "Belliphonic Sounds and Indoctrinated Ears: The Dynamics of Military Listening in Wartime Iraq." In Pop: When the World Falls Apart; Music and Troubled Times, edited by Eric Weisbard, 111-144. Durham, NC: Duke University Press, 2012. https://doi.org/10.1215/9780822394693-009.

\footnotetext{
${ }^{80}$ Kayhan Kalhor, personal communication, March 4, 2013.

${ }^{81}$ Hannah Arendt, The Human Condition, ed. Margaret Canovan (Chicago: University of Chicago Press, 1998), 210.
} 
Farhat, Hormoz. The Dastgāh Concept in Persian Music. Cambridge: Cambridge University Press, 2004.

"Halabja: Survivors Talk about Horror of Attack, Continuing Ordeal." Ekurd Daily: Independent Daily Newspaper, March 15, 2008. Accessed December 16, 2016. http://ekurd.net/mismas/articles/misc2008/3/independentstate2078.htm.

Haskell, Erica. "The Role of Applied Ethnomusicology in Post-Conflict and Post-Catastrophe Communities." In The Oxford Handbook of Applied Ethnomusicology, edited by Svanibor Pettan and Jeff Todd Titon, 453-80. Oxford: Oxford University Press, 2015.

Hiltermann, Joost R. A Poisonous Affair: America, Iraq, and the Gassing of Halabja. New York, NY: Cambridge University Press, 2007.

Losinski, Joseph. “'Ascending Bird' Silk Road Ensemble.” Artist Joseph Losinski (blog), April 12, 2013. Accessed December 16, 2016. http://aestheticjoe.wordpress.com/2013/04/12/ascending-bird-silkroad-ensemble/.

Kartomi, Margaret. "Toward a Methodology of War and Peace Studies in Ethnomusicology: The Case of Aceh, 1976-2009.” Ethnomusicology 54, no. 3 (2010): 452-83. https://doi.org/10.5406/ethnomusicology.54.3.0452.

Lewis, George. "Improvised Music After 1950: Afrological and Eurological Perspectives.” In The Other Side of Nowhere: Jazz, Improvisation, and Communities in Dialogue, edited by Daniel Fischlin and Ajay Heble, 131-62. Middletown, CT: Wesleyan University Press, 2004.

McDowell, John H. "Mexican Ballad as Commemorative Practice." In Music in the Post-9/11 World, edited by Jonathan Ritter and J. Martin Daughtry, 223-53. New York, NY: Routledge, 2007.

Miller, Debra A. Iraq. San Diego, CA: Greenhaven Press, 2004.

O'Connell, John M. and Salwa El-Shawan Castelo-Branco. Music and Conflict. Urbana, IL: University of Illinois Press, 2010.

Pettan, Svanibor. "Music in War, Music for Peace: Experience in Applied Ethnomusicology." In Music and Conflict, edited by John M. O’Connell and Salwa El-Shawan Castelo-Branco, 177-92. Urbana, IL: University of Illinois Press, 2010.

Pilzer, Joshua D. "The Study of Survivor's Music.” In The Oxford Handbook of Applied Ethnomusicology, edited by Svanibor Pettan and Jeff Todd Titon, 481-510. Oxford: Oxford University Press, 2015.

Rice, Timothy. "Ethnomusicology in Times of Trouble." Yearbook for Traditional Music 46 (2014): 191-209. https://doi.org/10.5921/yeartradmusi.46.2014.0191.

Ricoeur, Paul. Oneself as Another. Translated by Kathleen Blamey. Chicago: University of Chicago Press, 1992.

- Memory, History, Forgetting. Translated by Kathleen Blamey and David Pellauer. Chicago: University of Chicago Press, 2004. Kindle edition.

Ritter, Jonathan. “Terror in an Andean Key: Peasant Cosmopolitans Interpret 9/11.” In Music in the Post9/11 World, edited by Jonathan Ritter and J. Martin Daughtry, 177-208. New York: Routledge, 2007.

Silk Road Project, The. "The Silk Road Fact Sheet.” Accessed September 17, 2016. http://www.silkroadproject.org/tabid/144/Default.aspx.

Schweitzer, Vivien. “A Master Iranian Musician Plays Cultural Ambassador.” The New York Times, August 26, 2008. Accessed December 16, 2016. http://www.nytimes.com/2008/08/27/arts/music/27kayh.html?_r=1\&.

Stanyek, Jason. "Diasporic Improvisation and the Articulation of Intercultural Music." PhD diss., University of California, San Diego, 2004. 
Tangari, Joe. "Kayhan Kalhor and Brooklyn Rider: Silent City." Pitchfork, January 23, 2009. Accessed December 16, 2016. http://pitchfork.com/reviews/albums/12579-silent-city/.

\title{
Sound and Visual Sources
}

Kalhor, Kayhan. "Silkroad: Kayhan Kalhor on 'Silent City." YouTube video, 4:42, posted by "Silkroad" on August 24, 2011. Accessed December 16, 2016. https://www.youtube.com/watch?v=OWX3VLnoH_s.

Kayhan Kalhor and Brooklyn Rider. Silent City. Compact Disc published by World Village Records. 2005, 2008.

Kalhor and Brooklyn Rider. "Kayhan Kalhor and Brooklyn Rider: Silent City." YouTube video, 23:53, uploaded by "doostmusic" on March 2, 2011. Accessed December 16, 2016. https://www.youtube.com/watch?v=8WzIxBeJ78U.

Silk Road Ensemble, Yo-Yo Ma. Silk Road Journeys: When Strangers Meet. Compact Disc published by Sony Music Entertainment. 2001.

Silk Road Ensemble, Yo-Yo Ma, Chicago Symphony Orchestra, and Miguel Harth-Bedoya (conductor). New Impossibilities. Compact Disc published by Sony Music Entertainment. 2007.

\begin{abstract}
The musical collaboration of musicians of The Silk Road Ensemble in one of their well-received pieces, Silent City, commemorates Saddam Hussein's chemical attack in 1988 on the Iraqi Kurdish city of Halabja. Silent City was composed by the prominent Iranian kamancheh virtuoso, Kayhan Kalhor, for the Silk Road Ensemble in 2005. The musical collaboration of members of The Silk Road Ensemble serves as a case study to demonstrate how the commemoration of the victims of Halabja in their performance evinces the duty to remember for the sake of promoting justice in accordance with the logic of hope. It also asks how the memories of conflict and war are reflected in the music that incorporates elements of different musical traditions. The Silk Road Ensemble's performance of Silent City, as I argue, not only memorializes this tragic event and raise awareness but also provides a model for peaceful interactions that fosters a sense of intercultural hospitality.
\end{abstract}

